\title{
A Rare Case of a Renal Cell Carcinoma Metastasizing to the Mandible as Primary Presentation
}

Juan Liuzzi", Maribel Dacunha, Saul Siso and Esteban Garriga

Head and Neck Department, Padre Machado Oncological Hospital IVSS, Caracas, Venezuela

*Corresponding author: Juan Liuzzi, Head and Neck Department, Padre Machado Oncological Hospital IVSS, Caracas, Venezuela Tel: 00584166053436; E-mail: jfliuzzi@gmail.com

Received date: Dec 16, 2015; Accepted date: Dec 18, 2015; Published date: Dec 21, 2015

Copyright: (c) 2015 Liuzzi J, et al. This is an open-access article distributed under the terms of the Creative Commons Attribution License, which permits unrestricted use, distribution, and reproduction in any medium, provided the original author and source are credited.

\section{Text of Clinical Images}

Renal cell carcinoma is a frequent malignancy in adults that rarely metastasizes to the oral and maxillofacial region. A 54-years-old man presented with 3 months-history of gradually progressive swelling of the left-side mandibular body associated with pain. Oral examination revealed a mass in the left mandibular body, measuring approximately $6.0 \times 3.5 \mathrm{~cm}$. The head and neck CT showed an intraosseous tumor with lytic destruction of the left mandibular body. The biopsy of the mandible reported a clear cell adenocarcinoma. With the suspicious of a renal cell carcinoma metastasizing to the mandible, an abdominal CT was performed. The abdominal CT showed a tumor of the right kidney measuring $8.0 \times 7.0 \mathrm{~cm}$. It should be noted that the patient was completely asymptomatic of the renal tumor at the moment of the diagnosis.
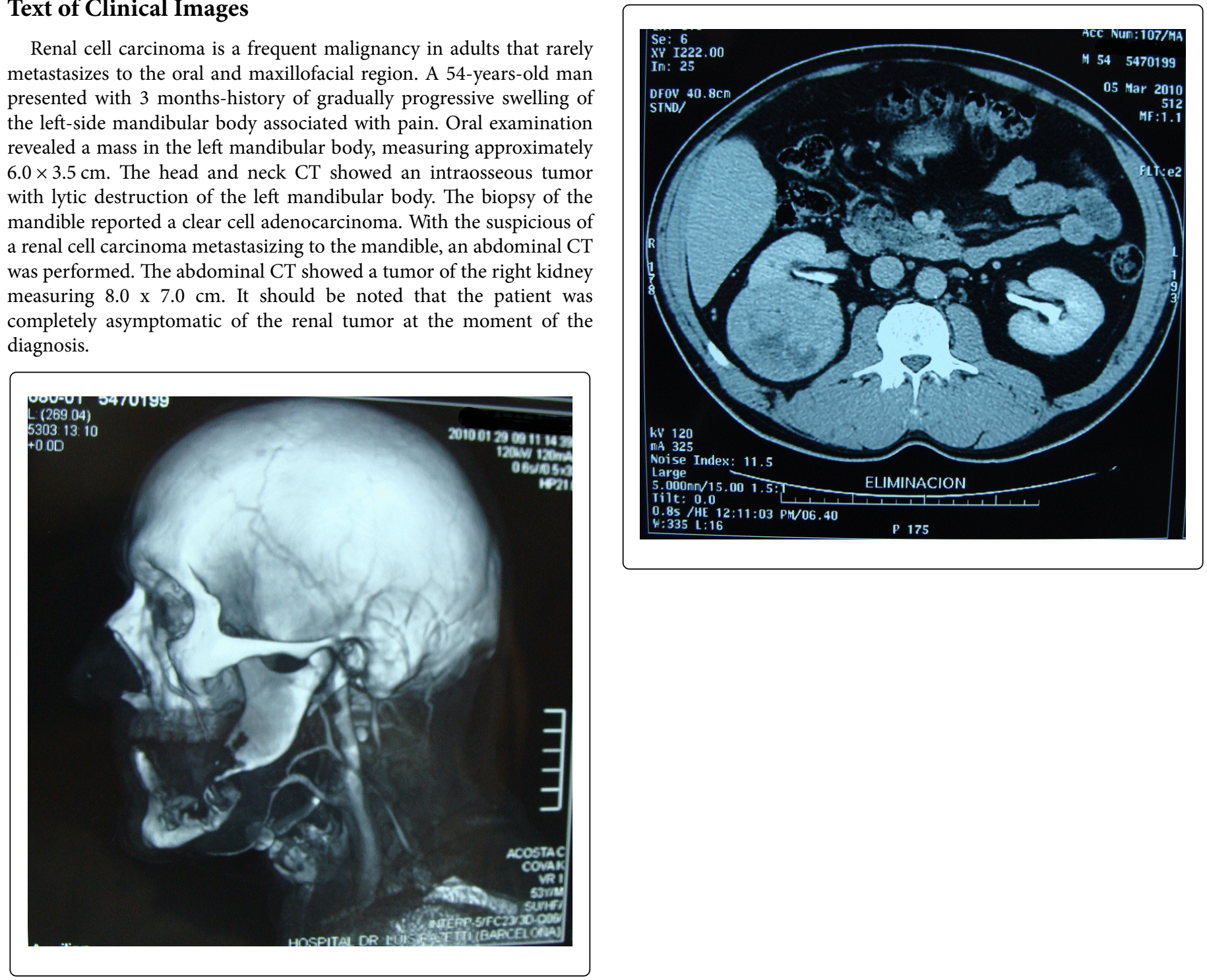